\title{
Effect of vernalizing temperature on the level of plant hormones in embryos of germinating grains of winter and spring wheat
}

\author{
M. MICHNIEWICZ, B. ROŹEJ, A. CHROMINSKI and Z. PORAZINSKI \\ Biological Institute, Copernicus University, Toruń, Poland
}

(Received: December 15, 1977.)

\begin{abstract}
In embryos of grains of winter and spring wheat germinating at temperature of $1.8-2.0^{\circ} \mathrm{C}$ the levels of auxins, gibberellins, cytokinins and abscisic acid-like inhibitor were determined. The analyses were performed after $5,10,20,40$ and 60 days of chilling. The levels of these hormones were also determined in embryos of grains germinated at $22^{\circ} \mathrm{C}$ being in the same growth stage as embryos taken from chilled grains. It was stated, that during the germination at vernalizing temperature the level of auxins, GAs and cytokinins increased in embryos of both varietes. The level of these hormones in winter wheat was however higher. The amount of growth inhibitor increased at the beginning of germination in embryos of both wheats and afterwards decreased. It was concluded that the above mentioned changes in the level of auxins, cytokinins and ABA had no direct relation to the process of vernalization. However, the changes in the levels of gibberellins found in embryos of winter wheat during the thermoinduction may be directly connected with the vernalization process.
\end{abstract}

\section{INTRODUCTION}

Our knowledge concerning the dynamics and role of plant hormones in vernalization process in scarce and controversial. Most information concerns gibberellins or auxins.

It is well known that vernalization can be replaced in some cases by gibberellins ( $\mathrm{L}$ a $\mathrm{ng}, 1965$ ). However, the information concerning the changes of these hormones in vernalization and their role in this process is controversial. According to some authors vernalization of winter wheat increases the level of GAs in plant tissues ( $\mathrm{Kent} z \mathrm{er}$, 1966; E1-Antably 1976; Reda and Larsen - cf. Reda 1976). However other authors did not observed such correlations ( $\mathrm{Krekule}$ and Telczerova, 1963; Romanova and Stasiljunas, 1969). 
Similarly lack of such correlation was found in experiments with cale (M a r g a r a, 1963) and Lunaria annua (Z e eva a r t, 1968). An increase in the level of GAs has been reported also in winter wheat, winter rye and winter annual Brassica napus ( $\mathrm{Chailakhian} \mathrm{et} \mathrm{al.,} \mathrm{1962,}$ 1963) as well as in radish (S u g e, 1970), Olea europea (B a d r e t a l., 1970) and Chrysanthemum morifolium (Tompsett and Schwabe, 1974) but in these experiments is was not established that the vernalization process itself resulted in the increased production of hormones.

Similarly the results of experiments on the influence of vernalization on the level of auxins are controversial (M ichniewicz, 1964). However, it was established that in winter wheat the process of vernalization does not depend upon the changes in the auxin level during the chilling of kernels ( $\mathrm{Michniewicz}$ and $\mathrm{Kamienska,1966).}$

The information concerning the influence of vernalization on the level of cytokinins are very scarce. However, it was found that the activity of these hormones increases during vernalization of winter wheat kernels (El-Antably 1976; Reda 1976) and in roots of chicory ( $\mathrm{J}$ o s e ph and Paulet, 1973).

There are many data showing that during the vernalization process the level of growth inhibitors decrease. This was found in experiments with winter wheat (Kentzer, 1960, 1966; M a rkowski 1964; Michniewicz and Kamieńska, 1966; El-Antably, 1976 and $\mathrm{Reda}$ and Larsen - cit. Reda, 1976), and with Olea europea (B a dr e t a l., 1970). Among these inhibitors the occurence of abscisic acid was stated (B a d r e t a l., 1970, El-Ant a bly, 1976). It must be underlined that our knowledge on the role and dynamics of plant hormones in vernalization process bases on the results of experiments performed with different plant material (e.g. with different plant species and organs) in which various methods were used. The analyses were commonly limited only to one or two hormones. We are also not sure if the changes obtained in the level of hormones were affected directly by chilling or they were caused by photoperiod.

Taking these remarks into consideration we decided to analyse simultaneously the level of gibberellins, auxins, cytokinins and abscisic acid like inhibitor during the vernalization in conditions excluding a possibility of the influence of photoperiod, and using uniform plant material. Our experiments were therefore aimed at the statement if the changes of the level of plant hormones are specific for vernalization process or they are only an effect of unspecific action of chilling.

\section{MATERIAL and METHODS}

For experiments winter wheat cv. 'Grana' and spring wheat cv. 'Urbanka' harvested in 1976 were used. The kernels were sterilized during $10 \mathrm{~min}$. with $0.2 \% \mathrm{HgCl}_{2}$ and then washed several times in 


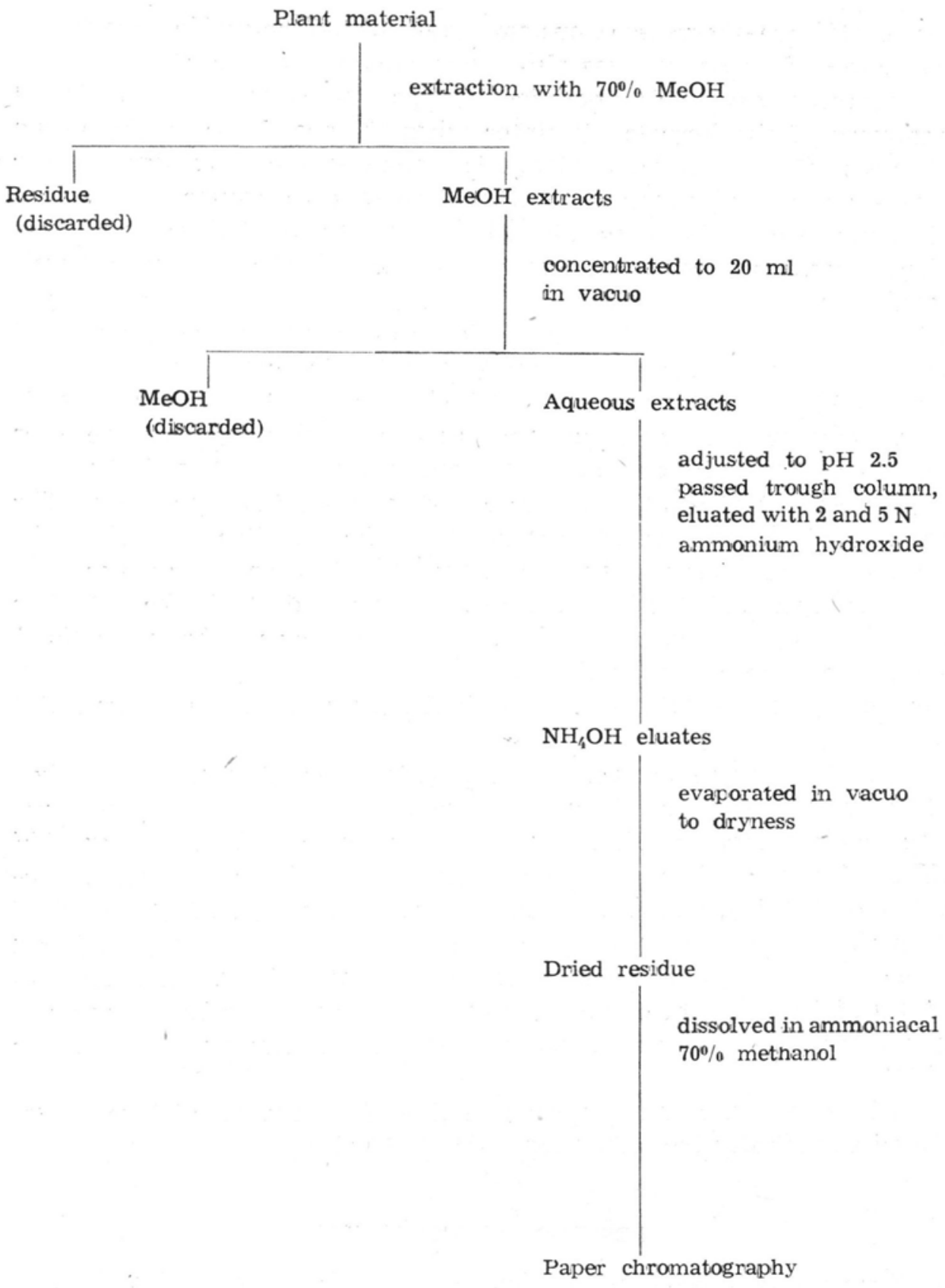

Fig. 1. Extraction and fractionation of cytokinins

destilled water. Such kernels were saturated with sterile distilled water to $45 \%$ of full saturation and germinated in darkness at $22^{\circ} \mathrm{C}$ during $24 \mathrm{hrs}$. Then half of the material was transfered to temperature 1.8$2.0^{\circ} \mathrm{C}$ and half remainded at $22^{\circ} \mathrm{C}$. The water content of grains amount- 
ing to $45 \%$ was kept at a constant level during the whole experimental period. The material was also every second day aerated.

In preliminary field experiment it was stated that 50 days of cold treatment of the kernels of winter wheat 'Grana' leads to the earing of about $50 \%$ of plants. Taking this statement into consideration, the analyses of plant hormones were performed with embryos after $24 \mathrm{hrs}$ of germination at $22^{\circ} \mathrm{C}$ and after $5,10,20,40$ and 60 days of chilling. Plant hormones were also determined in the embryos of kernels germinated at $22^{\circ} \mathrm{C}$ which reached the same growth stage as the embryos chilled during 10, 40 and 60 days. Kernels of winter wheat germinated at $22^{\circ} \mathrm{C}$ reached growth corresponding to 10,40 or 60 days of germination at low temperatures $1.8-2.0^{\circ} \mathrm{C}$ after 28,48 or $85 \mathrm{hrs}$ respectively. However kernels of spring wheat reached this growth stage after 28,36 or $68 \mathrm{hrs}$ of germination at room temperature respectively.

The content of plant hormones was determined in $50 \mathrm{~g}$ samples. The analyses of gibberellins, auxins and ABA-like inhibitor as well as the bioassays were made using methods described in a previous paper ( $\mathrm{M} \mathrm{i}$ $\mathrm{chniewicz}$ and $\mathrm{Galoch}, 1974)$. Auxins and ABA-like inhibitor were partitioned chromatographically on filter paper (Whatman's No 3) using the descending method and the solvent system-isopropanol: ammonia:water - 10:1:1 v/v. On each chromatogram an equivalent of 2 $\mathrm{g}$ fresh weight of embryos was spotted.

Cytokinins were extracted and purified according to the method of $\mathrm{H}$ e we $\mathrm{t} t$ and $\mathrm{W}$ a r eing (1973) exept that the polyvinylpyrollidine step was ommited (Fig. 1). The cation exchange column (Dowex 50W $\mathrm{X} 8 \mathrm{H}^{+} 50-100$ mesh) was applied, which was washed with $70 \%$ methanol and distilled water. The extracts were eluted with 2 and $5 \mathrm{~N}$ $\mathrm{NH}_{4} \mathrm{OH}$, and chromatographed on Whatman's No 1 paper (descending method) with isopropanol:ammonia:water - 10:1:1 v/v. An equivalent of $3 \mathrm{~g}$ of fresh weight of plant material was spotted on each chromatogram. The soybean tissue callus was used in the bioassay test (M ille r 1968).

All experiments were repeated 3 times and the results were evaluated statistically by estimating LSD at $\mathrm{P}=0.05$.

\section{RESULTS and DISCUSSION}

From the data presented in Fig. $2-5$ it is clear that during the cold treatment the level of gibberellins (Fig. 2) and auxins (Fig. 3) markedly increased and the activity of these plant hormones was higher in winter wheat than in the spring one. Similarly, but no such distict correlation appeared also in relation to cytokinins (Fig. 4). However, the level of ABA-like inhibitor increased at the beginning of chilling in both varieties and then markedly decreased (Fig. 5). 
Thus, the results concerning the changes of GA during the vernalization support the data of Kentzer (1966), El-A n tably $(1976,1977)$ and $\mathrm{Reda}$ and Larsen (cit. Reda 1976). However, they are in disaccordance with the results of $\mathrm{Krekule}$ and Telczerova (1963) as well as with those of Romanova and Stasiljunas (1969) who found no correlation between the cold treatment and the level of GAs in the embryos of winter and spring wheat.

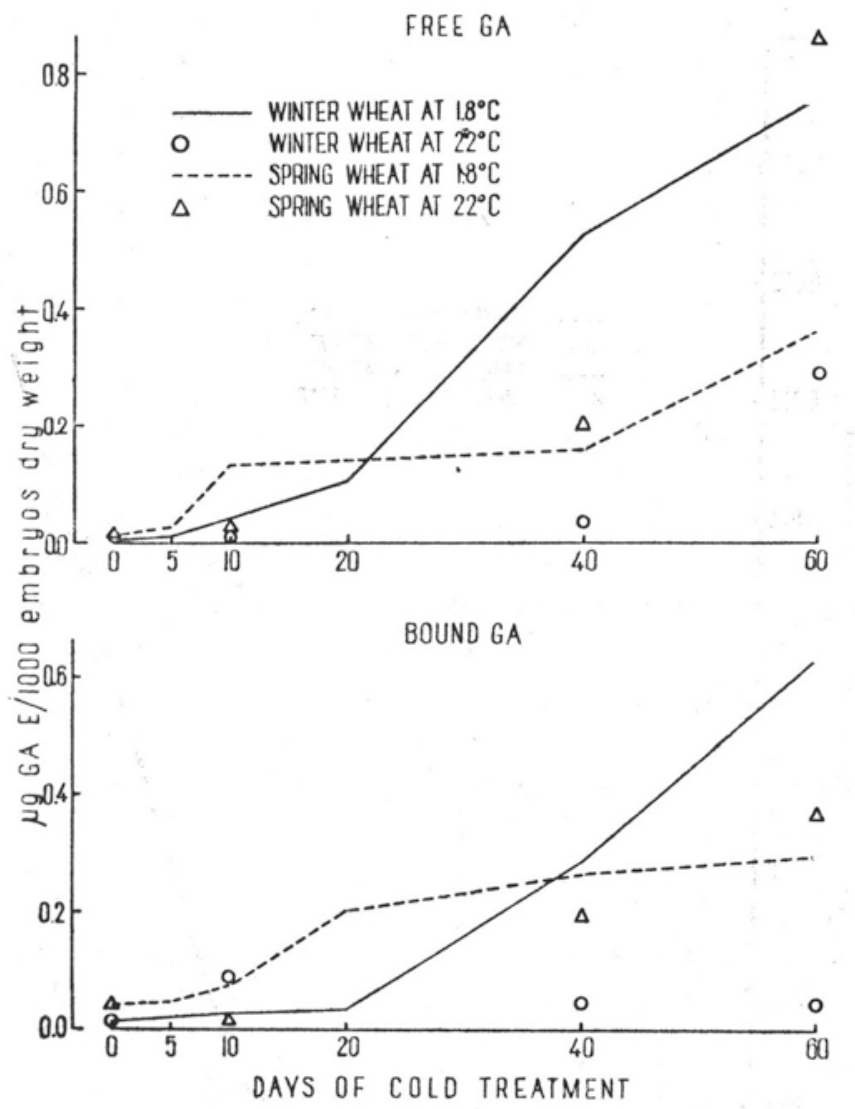

Fig. 2. Effect of cold treatment on gibberellin activity in embryos of winter and spring wheat

- the level of GAs in embryos of grains of winter wheat germinating at $22^{\circ} \mathrm{C}$

$\triangle-$ the level of GAs in embroys of grains of spring wheat germinating at $22^{\circ} \mathrm{C}$

Our results support also the data of $\mathrm{R}$ e d a (1976) and E l-A n t a b l y (1977) who proved that during the vernalization of winter wheat grains the level of cytokinins increased. They are also in accordance with the results of some authors who stated that vernalization decreases the level of growth inhibitors in plant material (K e n tzer, 1960, 1966; Markowski, 1964; M ichniewicz and Kamieńska, 1966; E l- 
-A n t a bly, 1976, 1977, and Reda and Larsen - cf. Reda, 1976). As to the auxins, the comparison of our results with the results of other authors is disconcerting because the data in the literature concerning this problem are very discordant (for review see $\mathrm{Michnie-}$ w i c z, 1964).

The comparison of the activities of plant hormones in embryos taken from chilled and unchilled kernels being in the same growth stages

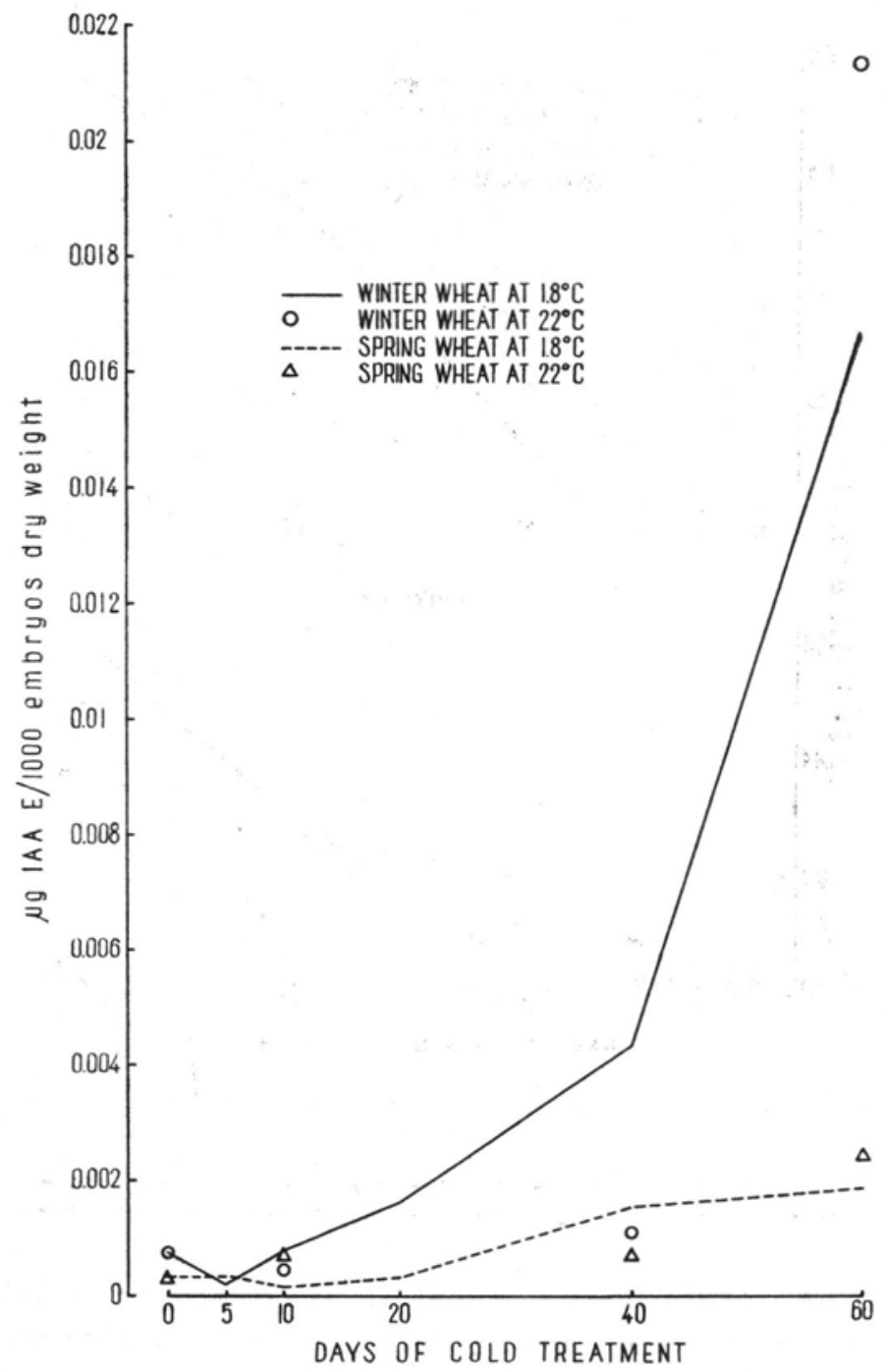

Fig. 3. Effect of cold treatment on auxin activity in embryos of winter and spring wheat

0 - the level of auxins in embryos of grains of winter wheat germinating at $22^{\circ} \mathrm{C}$

$\Delta-$ the level of auxins in embryos of grains of spring wheat germinating at $22^{\circ} \mathrm{C}$ 


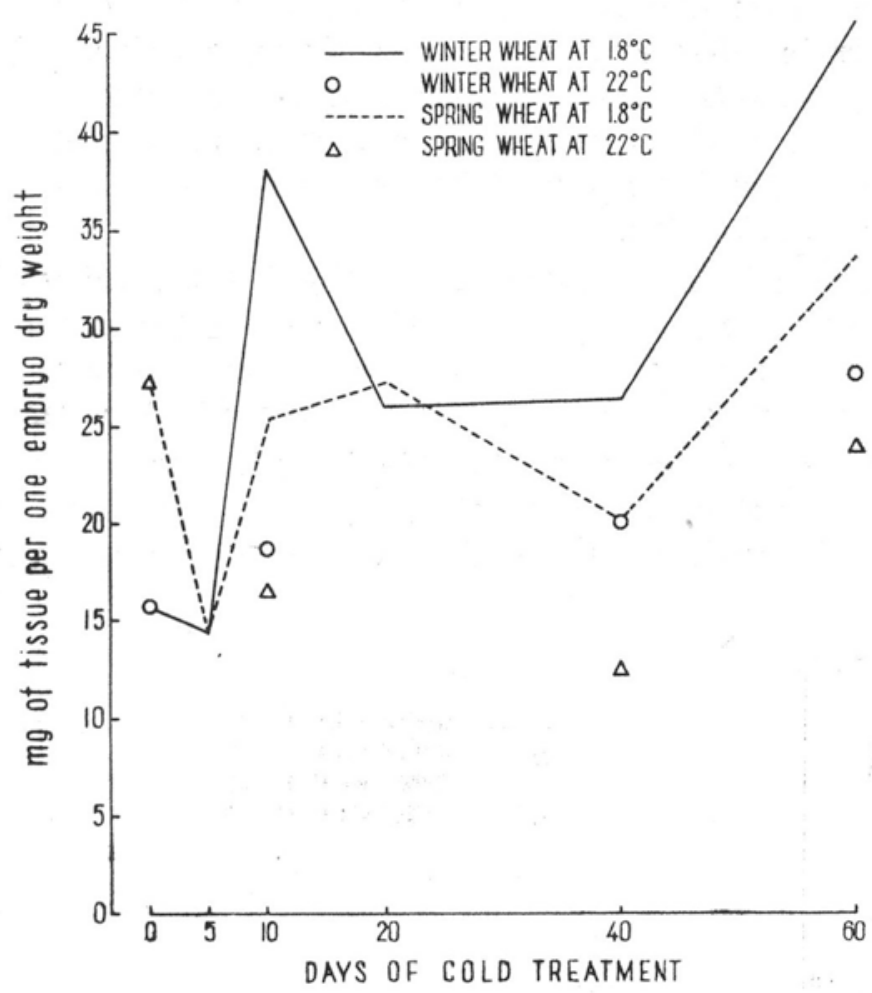

Fig. 4. Effect of cold treatment on total cytokinin activity in embryos of winter and spring wheat

$\mathrm{O}$ - the level of cytokinins in embryos of grains of winter wheat germinating at $22^{\circ} \mathrm{C}$

$\Delta-$ the level of cytokinins in embryos of grains of spring wheat germinating at $22^{\circ} \mathrm{C}$

elucidates the question whether or not the changes of the level of these substances observed as an effect of chilling are specific for vernalization. The data for such comparison are presented in Fig. $2-5$ and especially in Fig. 6-9 in which the activity of plant hormones is expressed in relation to the activity of these substances in unchilled embryos being in the same growth stage. From these data is clear that chilling affects differently the level of auxins in spring and winter wheat only at the beginning of cold treatment - increasing the level of auxins in the embryos of wheat cv. 'Grana' and decreasing it in the embryos of wheat cv. 'Urbanka'. Prolonged chilling influenced similarly the level of auxins in both varieties, increasing them after 40 days and markedly decreasing after 60 days of cold treatment (Fig 7). Thus, the increase of the activity of auxins in embryos observed during the vernalization (Fig. 3) is unspecific for this process. So, these results support our earlier conclusion basing on the results of experiments with spring and winter wheats, that the process of vernalization 
does not depend upon the changes in the activity of auxins during the chilling of kernels (Michniewicz and Kamieńska, 1966).

The data presented in Fig. 8 show that the chilling increases the level of cytokinins in wheat embryos. However, this increase is characterized for both wheats. Thus, it must be concluded that these changes are unspecific for vernalization.

As may be seen from the data presented in Fig. 9 chilling of kernels caused similar changes in the level ABA-like inhibitor in the embryos of both wheats. Consequently it must be concluded that also the effect of cold treatment on the level of $\mathrm{ABA}$ is unspecific for vernalization.

Strong increase of the level of ABA-like inhibitor observed in the first days of chilling might be explained by stress conditions caused by the transition of kernels from the room temperature to a low one. Such

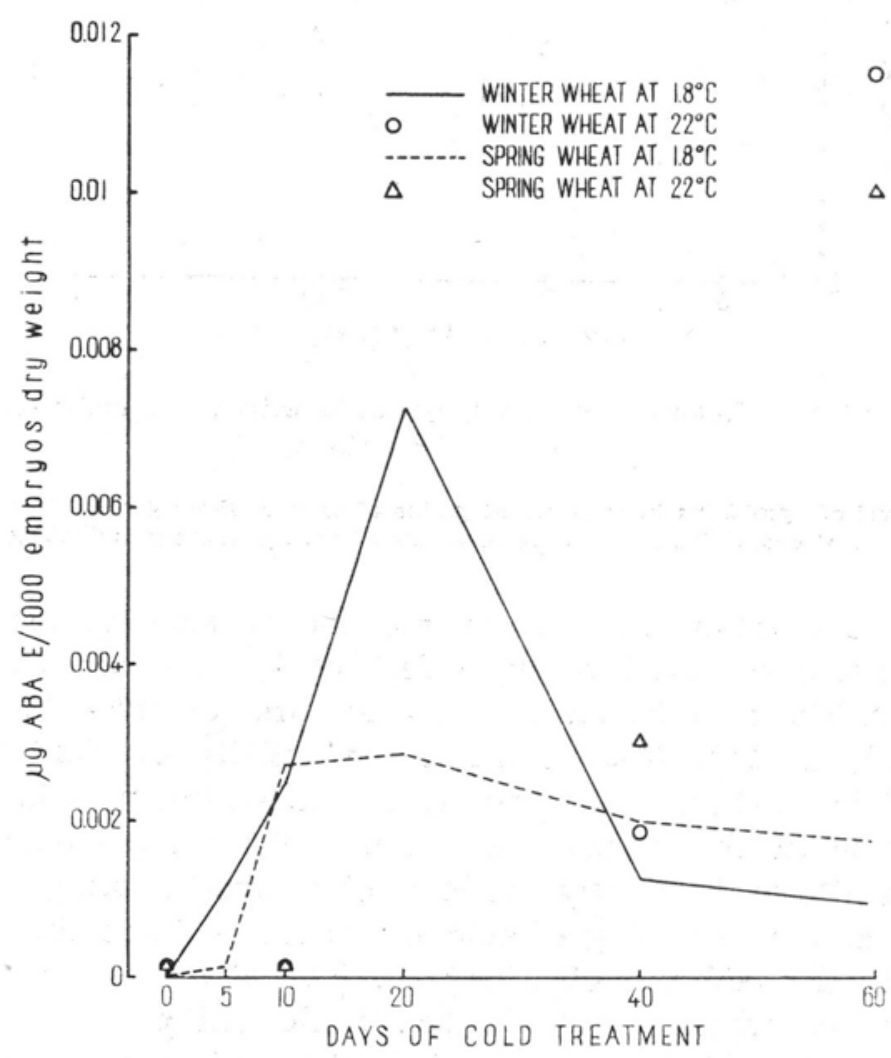

Fig. 5. Effect of cold treatment on abscisic acid activity in embryos of winter and spring wheat

$\mathrm{O}$ - the level of ABA in embryos of grains of spring wheat germinating at $22^{\circ} \mathrm{C}$ (control to 10 days of cold treatment $=1.3 \times 10^{-4} \mu \mathrm{g} \mathrm{ABA}$ E/1000 embryos)

$\triangle$ - the level of ABA in embryos of grains of winter wheat germinating at $22^{\circ} \mathrm{C}$ (control to 10 days of cold treatment $=0.7 \times 10^{-4} \mu \mathrm{g}$ ABA E $/ 1000$ embryos) 
effect of stress conditions was stated by some authors (W right and Hiron, 1970, Fedorova et. al., 1976). The decrease of ABA-like inhibitor in the further period of chilling would be understand assuming the fact that during the seed germination the level of this hormone decreases (Michniewicz, 1968; Michniewicz et al., 1974).
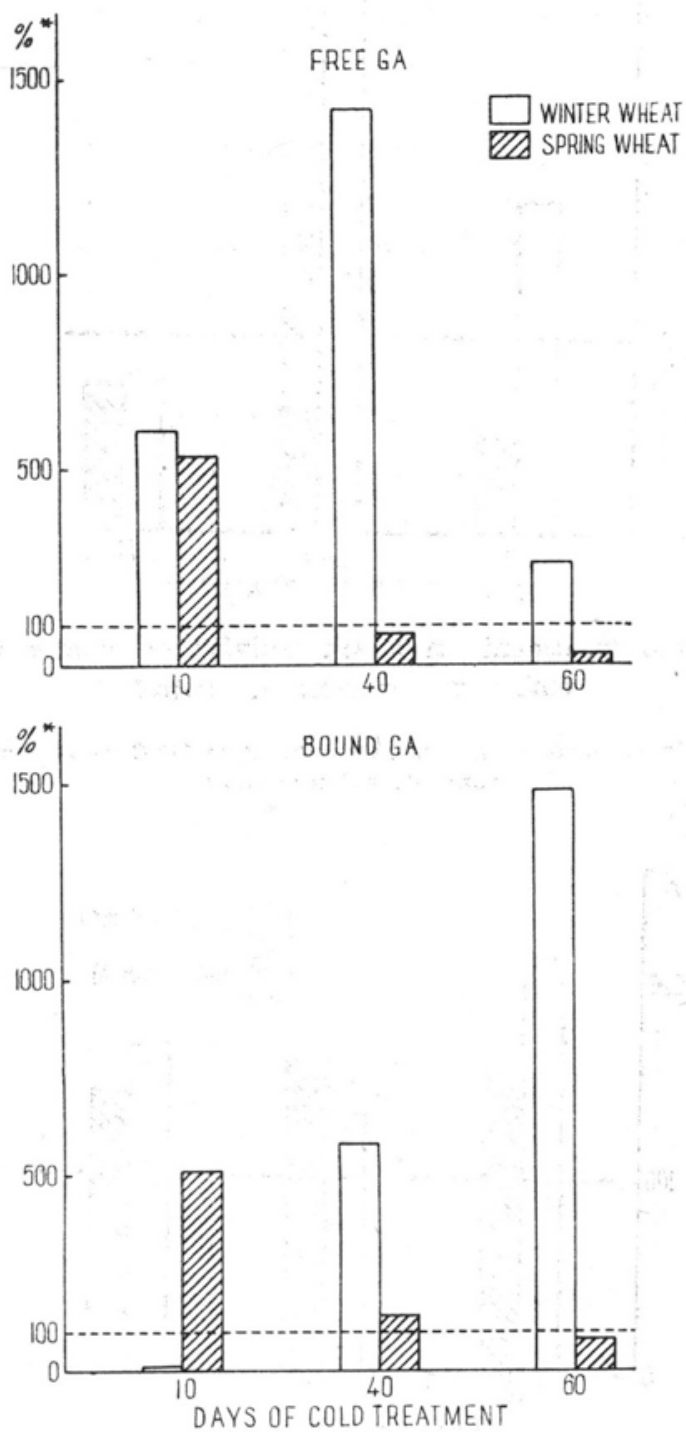

Fig. 6. Effect of cold treatment on gibberellin activity in winter and spring wheat embryos; in per cent of control

- the level of GAs in embryos of grains germinating at $22^{\circ} \mathrm{C}=100$ per cent for particular time of cold treatment 


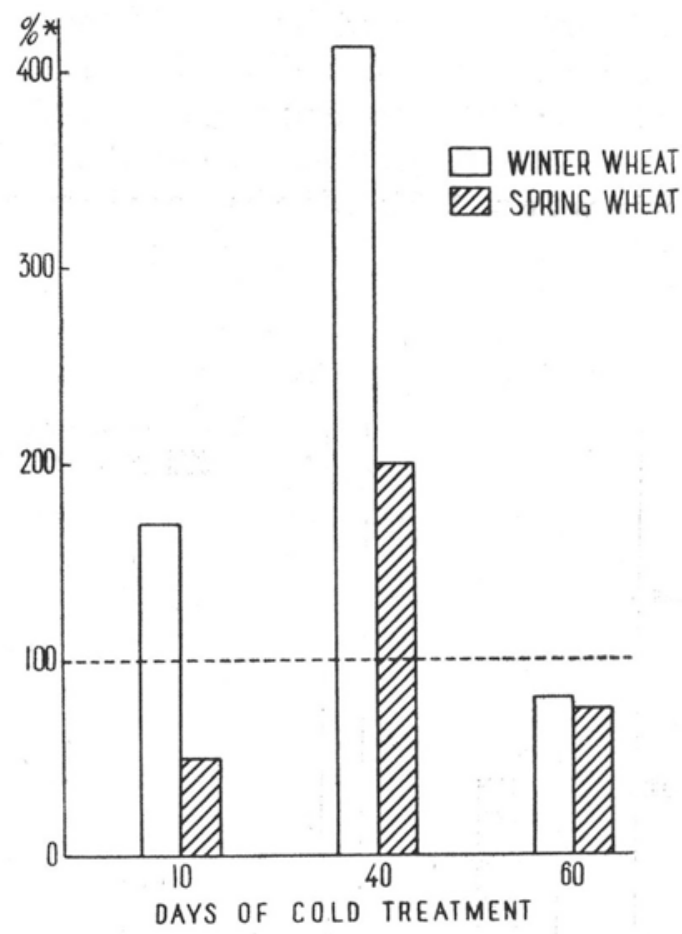

Fig. 7. Effect of cold treatment on auxin activity on winter and spring wheat embryos; per cent of control

- the level of auxins in embryos of grains germinating at $22^{\circ} \mathrm{C}=100$ per cent for particular time of cold treatment

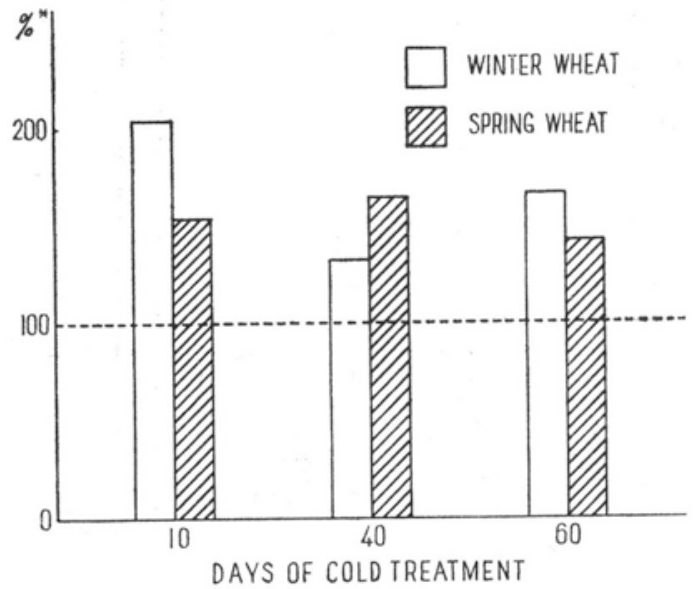

Fig. 8. Effect of cold treatment on cytokinin activity in winter and spring wheat embryos; in per cent of control

- the level of cytokinins in embryos of grains germinating at $22^{\circ} \mathrm{C}=100$ per cent for particular time of cold treatment 
It seems that in contrast to the above mentioned plant hormones, the changes in the level of GAs during the vernalization are specific for this process. This is evident from the data presented in Fig. 6. These data show that in winter wheat cold treatment increases the level of free GAs in all investigated stages of vernalization whereas in spring wheat the increase of these plant hormones was observed only in the early period of chilling. However, prolongation of chilling decreases

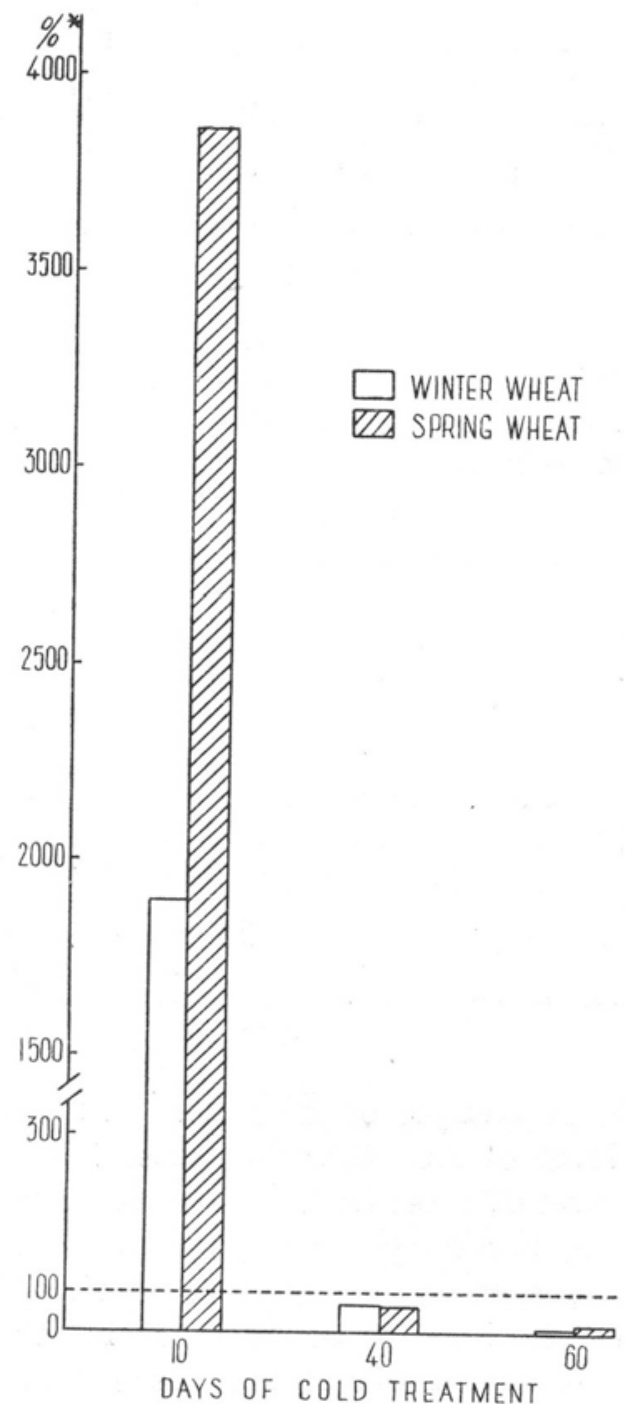

Fig. 9. Effect of cold treatment on abscisic acid activity in winter and spring wheat embryos; per cent of control

- the level of ABA in embryos of grains germinating at $22^{\circ} \mathrm{C}=100$ per cent for particular time of cold treatment 


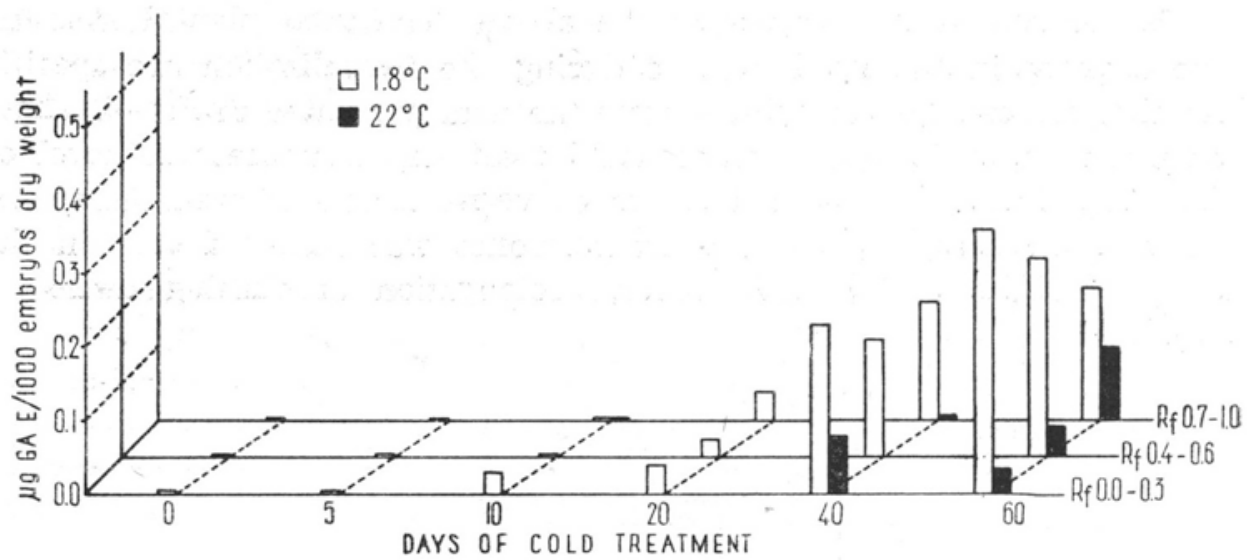

Fig. 10. Chromatographic analysis of gibberellins isolated from winter wheat embryos

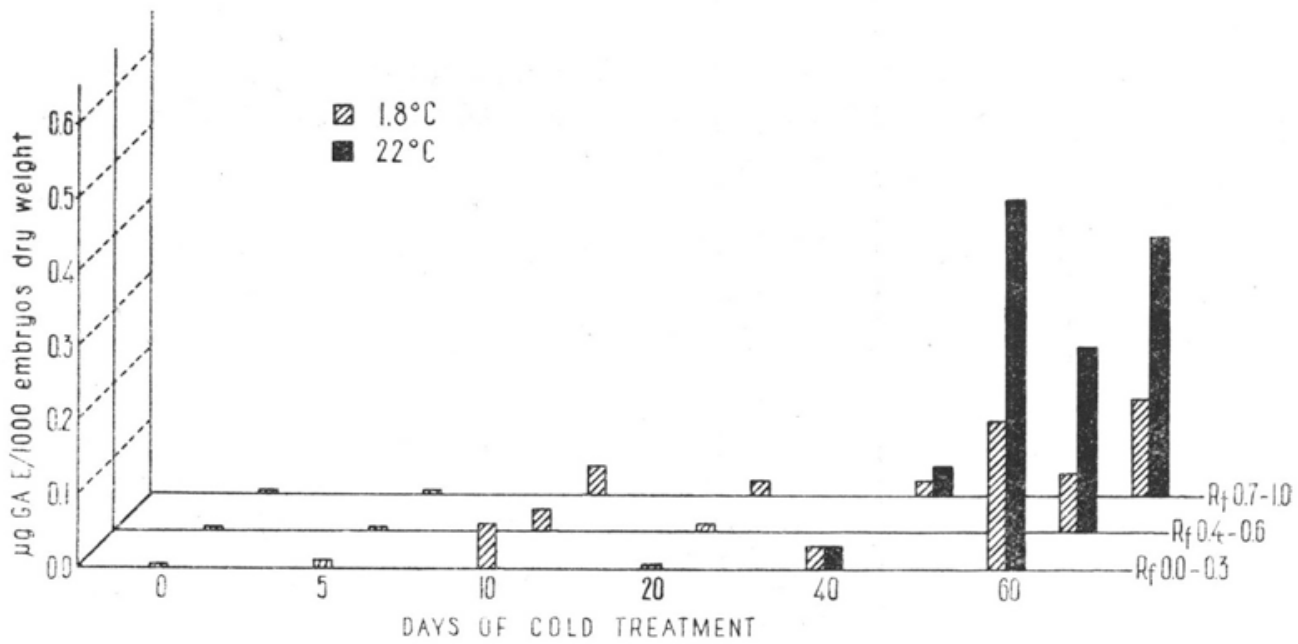

Fig. 11. Chromatographic analysis of gibberellins isolated from spring wheat embryos

the amount of GAs in embryos of this wheat. It must be also underlined that the highest level of free GAs and most impressed effect of cold treatment on the level of these hormones are correlated with the length of period of chilling necessary for full vernalization of winter wheat.

From the data presented in Fig. 6 it is also clear that the cold treatment decreases the level of bound GAs in the early period of vernalization. Presumably, these compounds are at this time utilized, being a source for the production of free GAs. The increase of bound GAs in later periods of chilling and simultaneous increase of free GAs may give evidence for high intensity of biosynthesis of gibberellins in the vernalization process. 
The results of this work permit for conclusion that among the investigated plant hormones only gibberellins might be considered specific for vernalization. However the question arrises concerning the qualitative changes of these hormones during vernalization.

Some information concerning this question gave us the results of analyses presented in Fig. 10 and Fig. 11. They show that in both wheats, irrespective of the conditions of growth and development of embryos, 3 groups of GA-like substances localized at $R_{f} \quad 0.0-0.3$, $0.4-0.6$ and $0.7-1.0$ were found. This statement does not exclude of course the possibility the occurrence of qualitative changes. However, necessary are further investigations and the use of many various solvent systems, various biotestes and some physicochemical methods of GA determination.

\section{CONCLUSIONS}

The results of our studies allow to conclude that the changes in the level of auxins, cytokinins and abscisic acid found in wheat embryos as an effect of cold treatment are not directly connected with the vernalization process. Specific for vernalization may be only the changes in the level of gibberellins which take place in embryos during thermoinduction

\section{REFERENCES}

Badr S. A., Hartmann H. T., Mart in G. C., 1970. Endogenous gibberellins and inhibitors in relation to flower induction and inflorescences development in the olive. Plant Physiol. 46:674 679 .

Chailakhian M. Kh., Lozhnikova V. N.', 1962. Gibberellin-like substances and vernalization of plants. Plant Physiol. (Moscow) 9:21-31.

Chailakhian M. Kh., Nekrasova T. V., Khlopenkova L. P., Lozhnik ova V. N., 1963. The role of gibberellins in the processes of photoperiodism, vernalization and stratification of plants. Plant Physiol. (Moscow) 10:465-476.

El-A n t a bly H. M. M., 1976. Endogenous hormone levels in vernalized roots and shoots of wheats seedlings. Biochem. Physiol. Pflanzen. 170:59-65.

El-Antably H. M. M., 1977. Endogenous hormone levels in vernalized seed, apex, and leaves of wheat seedlings. Biochem. Physiol. Pflanzen 171:261-267.

Fedorova A. I., Gagulaeva A. P., Molokova N. I., 1976. The correlaticr between the content of abscisic acid in Siberian fir (Larix sibirica) and its growth rate. Plant Physiol. (Moscow) 23:80-87.

Hewett E. W., Wareing P. F., 1973. Cytokinins in Populus $\times$ robusta: Changes during chilling and bud burst. Physiol. Plant. 28:393-399.

J os eph C., Paulet P., 1973. Variations de la teneur en cytokinines endogénes dans la racine de Cichorium intybus $\mathrm{L}$. en function du traitement de vernalisation par le froid. C. R. Acad. Sc. Paris 277, Ser. D:785-788.

Kentzer T., 1960. Dynamics of growth regulators in the process of vernalization of winter wheat Leszczyńska Wczesna. Zesz. Nauk. UMK Toruń, Biol. 4:27-63. 
Kentzer T., 1966. The influence of the light factor on the dynamic of endogenous growth regulating substances in vernalized and unvernalized winter wheat (Triticum aestivum L.). Proceed. of a Symposium Praha-Nitra, August 30 September 6, $1964: 89-93$.

Krekule J. Telczerova L., 1963. Uber den gehalt an auxin- und gibberellinahnlichen stoffen bei jarowisierten und nicht jarowisierten embryonen von sommer- und winterweizen. Biol. Plantarum 5:252-257.

L a ing A., 1965. Physiology of flower initiation. In: W. Ruhland, ed., Handbuch der Pflanzenphysiologie, Vol. XV/1. Springer-Verlag, Berlin :1380-1536.

Margara J., 1963. Role éventual de gibbérellines endogénes dans le développement de Colza. Physiol. Vég. 1:315-324.

Markowski M., Piskornlik Z., 1964. Changes in growth substances of the auxin type in embryos of winter and spring wheat in the course of germination at $22^{\circ} \mathrm{C}$ and at vernalization temperature $\left(1.5^{\circ} \mathrm{C}\right)$. Bull. Acad. Polon. Sci., Ser. Biol. II-XII, 9:407-411.

Michniewicz M., 1964. Krytyczna acena dotychczasowego stanu badań nad rolą czynnika hormonalnego w procesie jaryzacji. Postępy Nauk Roln. (Warsaw) 88:95-114.

Michniewicz M., 1968. Plant growth regulators in the seeds of pine. Intern. Symp. on Seed Physiol. of Woody Plants. Ed. Inst. Dendrology, Kórnik: $31-37$.

Michniewicz M., Galoch E., 1974. The role of vanillin and p-coumaric acid in the growth of Scotch pine seedlings. Acta Soc. Boit. Polon. 43:275-281.

Michniewicz M., Galoch E., Rożej B., Zatorska Z., 1974. Dynamics of endogenous plant growth regulators in the early stages of growth and development of Scotch pine seedlings (Pinus silvestris L.). Bull. Acad. Polon. Sci., Ser. Biol. 22:625-631.

Michniewicz M., Kamieńska A., 1966. Studies on the dynamics of growth regulators in spring and winter wheats during the period of germination. II. Plant growth regulators in vernalized and in non-vernalized wheats. Zesz Nauk. UMK Toruń, Biol. 8:105-111.

Miller C. O., 1968. Biochemistry and physiology of plant growth substances. (F. Wightman, G. Sellerfield eds). Runge Press, Ottawa, Canada :33.

R eda F., 1976. Endogenous cytokinins in vernalized winter wheat grains. Plants (Berl.) 130:265-268.

Romanova V., Stasiljunas O. A., 1969. Gibberellinopodobnye veśćestva v list'jach ozimoj pśenicy $v$ svjazi $z$ jarovizaciej. Dokł. Vaschnił. 2:7-9.

$\mathrm{Suge} \mathrm{H.,} \mathrm{1970.} \mathrm{Changes} \mathrm{of} \mathrm{endogenous} \mathrm{gibberellins} \mathrm{in} \mathrm{vernalized} \mathrm{radish} \mathrm{plants.}$ Plant Cell Physiol. 11:729-735.

Tompseit P. B., S chw a be W. W., 1974. Growth hormone changes in Chrysanthemum morifolium. Effects of environmental factors controlling flowering. Ann. Bot. 38:269-285.

Wright S. T., Hiron R. W. P., 1970. The accumulation of abscisic acid in plants during wilting and under other stress conditions. Plant Growth Substances. Ed. D. J. Carr, Berlin-Heidelberg-New York :291-298.

Z e eva art J. A. D., 1968. Vernalization and gibberellins in Lunaria annua L. Biochem. and Physiol. of Plant Growth Substanees. The Runge Press. Ltd. Ottawa, Canada :1357-1370.

Authors' address:

Prof. dr. Marian Michniewicz and co-authors, Institute of Biology, Copernicus University; Gagarina Str. 9; 87-100 Toruń; Poland 
Wpływ temperatury jaryzującej na poziom fitohormonów $w$ embrionach pszenicy ozimej $i$ jarej*

\section{Streszczenie}

Określono poziom auksyn, giberelin, cytokinin i ABA w embrionach pszenicy ozimej i jarej uzyskanych $\mathrm{z}$ ziarna poddanego chłodzeniu $\mathrm{w}$ temperatur7e 1,8-$2,0^{\circ} \mathrm{C}$. Analiz dokonywano po $5,10,20,40$ i 60 -ciu dniach chłodzenia. Oznaczano również poziom tych substancji $\mathrm{w}$ embrionach pochodzących $\mathrm{z}$ ziarna kiełkującego w temperaturze $22^{\circ} \mathrm{C}$, które osiągnęly taką fazę wzrostu jak embriony pochodzące z ziarna traktowanego chłodem. Stwierdzono, że w miarę działania chłodem zwiększa się poziom giberelin, auksyn i cytokinin i jest on wyższy u odmiany ozimej aniżeli u jarej. Poziom ABA rośnie w początkowym etapie chłodzenia u obu odmian, a następnie wyraźnie maleje. Wykazano, że zmiany te dotyczące auksyn, cytokinin i ABA nie mają bezpośredniego związku z procesem jaryzacji. Specyficzne dla tego procesu mogą być natomiast zmiany w poziomie giberelin jakie zachodzą w embrionach podczas termoindukcji.

* Praca wykonana w ramach tematu węzlơwego Nr 09.7.3.1.5. 